\title{
ISLAMIC EDUCATION REORIENTATION IN GROWING THE FITRAH OF GOODNESS IN THE ERA OF GLOBALIZATION
}

\author{
Nursaid $^{1}$, Nur Khozin ${ }^{2}$ \\ Program Studi PAI FITK IAIN Ambon \\ Khozinpai@gmail.com
}

\begin{abstract}
Abstrak: Tujuan penelitian adalah untuk mengetahui bagaimana posisi lembaga pendidikan Islam di era globalisasi yang serba transparan. Lembaga keluarga menjadi pondasi utama bagi pertumbuhan dan perkembangan generasi zaman sekarang. Peran keluarga dimotori kedua orang tua, peran sekolah dimotori para guru, masyarakat di motori para tokoh masyarakat dan di perguruan tinggi dimotori oleh para dosen untuk menumbuhkan fitrah beragama dalam menginternalisasikan keimanan dan menumbuhkan fitrah kebaikan.

Penelitian ini adalah penelitian kualitatif pendekatan deskriptif yaitu untuk mendeskripsikan suatu gejala, peristiwa, kejadian yang terjadi lapangan. pengumpulan data peneliti menggunakan observasi, kemudian peneliti juga melakukan kegiatan Focus Group Discussion (FGD) merupakan bentuk kegiatan pengumpulan data melalui diskusi kelompok dan pembahasan dalam kelompok. Teknik analisis Data menggunakan reduksi data, penyajian data, penarikan kesimpulan.

Dari penelitian ini ditemukan bahwa perlu adanya reorientasi visi dan misi pendidikan Islam. dengan visi dan misi besar yang menghasilkan keluaran yang mantap. Jika menginginkan peserta menjadi kembali ke fitrahnya, maka pendidikan Islam pada prosesnya dibutuhkan kemauan yang besar untuk mewujudkan visi dan misinya, sehingga fitrah kebaikan yang telah ada pada diri peserta didik dapat tumbuh dengan baik sebagai insan kamil. Perlu adanya Reorientasi Strategi Pendidikan Islam yaitu membutuhkan untuk peningkatan mutu dan pemerataan pendidikan pada semua lembaga pendidikan. Untuk menumbuhkan fitrah perlu penumbuhan karakter visi ulul al-bab, al-ulama, al-muzakki, ahl al-dzikr, dan al-rasikhuna fi al-'ilm dan memposisikan pendidik yang berwibawa dan memiliki sakralitas. Perlu optimalisasi pembelajaran dan internalisasi tugas utama guru sebagai profesi, kemanusiaan, kemasyarakatan mutu pendidik pendidikan Islam dari berbagai sisi di era globalisasi.
\end{abstract}

Kata Kunci: Pendidikan Islam, Fitrah Kebaikan, Era Globalisasi

\section{PENDAHULUAN}

Perkembangan dan pertumbuhan generasi di era globalisasi ini tergantung dari proses yang dilalui melalui generasi zaman dulu. Era globalisasi mempengaruhi perkembangan sosial budaya masyarakat muslim Indonesia, termasuk pendidikan Islam. Masyarakat muslim tidak bisa menghindarkan diri dari proses globalisasi, apalagi jika ingin berjaya ditengah perkembangan dunia di abad 21 yang kian kompetitif. (Azyumardi Azra, 2014: 41).

Mula-mula, sumber globalisasi itu adalah timur tengah, khususnya Mekkah dan Madinah sejak abad ke-16, dan sejak akhir abad ke-19 dan 
awal abad ke-20 adalah Kairo. Sehingga, masyarakat muslim tidaklah kaget dengan hal ini, karena globalisasi ini bersifat religio-intelektual. (Azyumardi Azra, 2014: 41).

Namun, globalisasi yang berlangsung dan melanda masyarakat muslim saat ini menampilkan sumber berbeda. Globalisasi saat ini bukan dari Timur Tengah tetapi dari Barat yang terus memegang supremasi dan hegemoni dalam berbagai lapangan kehidupan masyarakat dunia. Globalisasi yang bersumber dari Barat tampil dengan watak ekonomi-politik dan sains-teknologi. Dominasi dan hegemoni Barat dalam segi tertentu mungkin saja telah merosot, khususnya sejak berakhirnya Perang Dunia II dan Perang Dingin, tetapi hegemoni ekonomi dan sains-teknologi Barattetap belum tergoyahkan. Meskipun muncul beberapa kekuatan ekonomi baru, seperti Jepang, Korea Selatan, China, dan India, tetapi kultur hegemoni ekonomi dan sains-teknologi tetap sarat dengan nilai Barat. Hegemoni tersebut menemukan momentum baru yang pada gilirannya mempercepat globalisasi. (Azyumardi Azra, 2014: 42).

Pendidikan dan pranata keluarga menjadi benteng pertama dan utama dalam memperoleh kasih sayang, pertumbuhan, perlindungan, pendidikan agama dan pendidikan sosial. Di abad 21 yang serba transparan dari berbagai budaya, keluarga menjadi pondasi utama bagi pertumbuhan dan perkembangan generasi zaman sekarang. Keluarga perlu memberikan fungsi dan perannya dengan penuh tanggung jawab.

Fenomena gagap teknologi memunculkan sebuah pertanyaan, bagaimana membuka diri terhadap perkembangan zaman tanpa terhanyut dengan arus negatif yang menyertai. Dampak yang dapat dipastikan menjadi korbannya, yaitu anak-anak dan remaja. Secara psikologi, anakanak merupakan peniru yang hebat.Mereka juga sangat mudah mempelajari sesuatu bahkan tanpa bimbingan orang dewasa. Remaja yang sedang mengalami masa transisi dan masa labilitas dari anak-anak menuju dewasa, cenderung tidak mudah untuk mendengarkan pendapat orang lain, sekalipun pendapat itu benar. 
Guna mengantisipasi fenomena tersebut di atas, dibutuhkan peran dari keluarga, sekolah, dan masyarakat serta perguruan tinggi secara santun dan bijaksana dalam menjalankan tugasnya masing-masing. Peran keluarga dimotori kedua orang tua, peran sekolah dimotori para guru, masyarakat dimotori para tokoh masyarakat dan di Perguruan Tinggi dimotori oleh para dosen. Dalam menjalankan peranya keluarga dalam menjalankan perannya memiliki tugas utama, yaitu menumbuhkan fitrah beragama, dasar pendidikan pertama, terutama dalam menginternalisasikan keimanan dan al-Qur'an, sehingga tugas utama dalam menumbuhkan kemauan menginternalisasikan keimanan dan alQur'an menjadi kewajiban orang tua atau keluarga. Orang tua sebagai pendidik pertama dan utama memiliki tugas, yaitu menjadi teladan utama, menjadi pendidik utama, menjadi motivator, dan menjadi kepala sekolah kehidupan. (Irawati Istadi, 2017: 25-27).

Masyarakat dalam menjalankan tugasnya menjadi kontrol sosial dan sekaligus pengguna langsung yang merasakan, sehingga dibutuhkan peran serta masyarakat dalam mengontrol akhlak generasi muda. Kepedulian masyarakat sangat memberikan pengaruh yang sangat besar bagi pertumbuhan dan perkembangan generasi yang dilahirkan.

Guru yang profesional adalah guru yang menjunjung tinggi prinsipprinsip profesionalisme dalam menjalankan profesinya. Guru yang kompeten harus memahami dan menerapkan nilai-nilai profesionalisme dalam menjalankan karis profesinya. Apabila nilai-nilai ini dijalankan dengan sepenuh hati maka tentunya profesi guru akan mendarah daging dalam diri setiap guru dan mereka akan memberikan pengabdian totalitas sebagai guru (Jumaeda, 2018: 103-104), sehingga penanaman nilai-nilai fitrah peserta didik akan mudah dicapai.

Begitu pula perguruan tinggi yang siap mengembangkan watak dan karakter mahasiswa yang bermartabat, mengembangkan ilmu pengetahuan dan teknologi dengan memperhatikan nilai-nilai fitrah. Perguruan Tinggi harus mengembangkan generasi yang inovatif, 
responsive, kreatif, terampil, dan bertanggung jawab mengembangkan potensi mahasiswa yang bertakwa kepada Tuhan Yang Maha Esa. (UU No.12 Tahun 2012 Pasal 5). Sinergi antara orang tua, guru, dan masyarakat menjadi kunci keberhasilan pendidikan dalam menumbuhkan fitrah pada generasi penerus yang hidup di zaman modern.

Pendidikan membantu mahasiswa untuk memperoleh pengetahuan dan pengembangan diri terhadap potensi yang dimiliki dan menjadi pribadi yang berkarakter dan baik bagi dirinya, keluarga dan masyarakat. Karakter merupakan sifat kepribadian yang khas pada tiap individu dan tampak dalam kehidupan sehari-hari dalam bertindak. Nur Khozin dkk, 2018: 53).

Generasi zaman sekarang merupakan generasi yang sangat besar pengaruhnya dengan kehidupan bangsa di masa mendatang. Pada generasi ini, tertumpu harapan masa depan yang sangat besar, karena mereka adalah para calon ulama, calon pemimpin, calon pendidik, calon ekonom, calon ilmuwan, calon dokter, dan orang tua di masa depan.

Orang tua, pendidik, masyarakat tidak bisa apatis menyaksikan begitu dahsyatnya gelombang persatuan generasi ini yang mulai sulit dikendalikan. Ibarat layang-layang, bukan lagi angin yang menerbangkannya ke kanan dan ke kiri hingga sulit dipegang, melainkan layang-layang itu sendiri yang bergerak begitu cepatnya seakan tali kekang itu akan putus.

Era globalisasi memberikan tantangan tersendiri untuk mengejar kemajuan dan sejajar dengan daerah telah maju. Usaha yang besar, sungguh-sungguh, konsisten dan berkelanjutan tentu saja mutlak dibutuhkan. (A. Hanief Saha Ghafur, 2009: 8). Orang tua, guru, masyarakat dan dosen harus mampu berinovasi. Para pendidik harus mampu mengubah secara total paradigma lama yang mereka anut dan menginstallnya dengan paradigma baru yang sesuai dengan perkembangan zaman yang ada. Kualitas pendidik tidak saja memberikan harapan akan lahirnya mahasiswa-mahasiswa yang unggul dalam ilmu pengetahuan, 
memahami fitrahnya, menjunjung tinggi peradaban masyarakat, harkat dan martabat manusia.

\section{METODE}

Penelitian ini adalah penelitian kualitatif yang menghasilkan data deskriptif. Pendekatan yang dipakai oleh peneliti adalah pendekatan deskriptif,yaitu untuk mendeskripsikan suatu gejala, peristiwa, kejadian yang terjadi lapangan. Dalam pengumpulan data peneliti menggunakan observasi, kemudian peneliti juga melakukan kegiatan Focus Group Discussion (FGD) yang merupakan bentuk kegiatan pengumpulan data melalui diskusi kelompok dan pembahasan dalam kelompok sebagai alat/media paling umum digunakan dalam metode penelitian. Sedangkan Teknik analisis Data menggunakan Display dataPenyajian Data (Data Display) dan Ferifikasi Data (Conclusion Drawing).

\section{HASIL}

Pendidikan Islam sebagai subsistem pendidikan nasional perlu melakukan perubahan paradigma dalam pendidikan, paling tidak pendidikan akan berpengaruh terhadap perubahan pada masyarakat. Proses perubahan paradigma yang mengarah pada perubahan sistem pendidikan harus dilakukan secara terencana dengan langkah-langkah yang strategis, yaitu mengidentifikasi berbagai problem yang menghambat terlaksananya pendidikan dan merumuskan langkah-langkah pembaruan yang lebih bersifat strategis dan praktis sehingga dapat diimplementasikan di lapangan atau lebih bersifat operasional.

Ada dua alasan pokok mengapa konsep pembaharuan pendidikan Islam di Indonesia. Pertama, konsep dan praktik pendidikan Islam dirasakan terlalu sempit, artinya terlalu menekankan pada kepentingan akhirat, sedangkan ajaran Islam menekankan pada keseimbangan antara kepentingan dunia dan akhirat. Kedua, lembaga-lembaga pendidikan Islam yang dimiliki sekarang ini, belum atau kurang mampu memenuhi kebutuhan umat Islam dalam menghadapi tantangan dunia modern dan tantangan masyarakat dan bangsa Indonesia disegala bidang. Suatu usaha 
pembaharuan pendidikan hanya bisa terarah dengan mantap apabila didasarkan pada beberapa strategi dan langkah-langkah yang perlu dilakukan, yaitu:

Pertama, reorientasi kerangka dasar filosofis dan teoritis pendidikan. Filsafat pendidikan yang mantap hanya dapat dikembangkan di atas dasar asumsi-asumsi dasar yang kokoh dan jelas tentang manusia (hakekat) kejadiannya, potensi-potensi bawaannya, ${ }^{1}$ tujuan hidup dan misinya di dunia ini baik sebagi individu maupun sebagai anggota masyarakat, hubungan dengan lingkungan dan alam semesta dan akhiratnya hubungan dengan Maha Pencipta. Teori pendidikan yang mantap hanya dapat dikembangkan atas dasar pertemuan antara penerapan atau pendekatan filsafat dan pendekatan emperis. Sehubungan dengan itu, konsep dasar pembaharuan pendidikan Islam adalah perumusan konsep filsafat dan teoritis pendidikan yang didasarkan pada asumsi-asumsi dasar tentang manusia dan hubungannya dengan lingkungan dan menurut ajaran Islam. Mohammad Muchlis Solichin, 2007: 243-245; Muhaimin, 2002: 19).

Atas dasar konsep ini, maka konsep filsafat dan teoritis pendidikan Islam dikembangkan sebagai prinsip-prinsip yang mendasari keterlaksanaannya dalam kontek lingkungan masyarakat rabbani tersebut, sehingga pendidikan relevan dengan kondisi dan ciri sosial kultural

${ }^{1}$ Potensi-potensi itu dalam bahasa agama disebut fitrah. Konsep fitrah menunjukkan bahwa manusia membawa sifat dasar kebajikan dengan potensi iman (kepercayaan) terhadap keesaan Tuhan (tauhîd). Alat-alat potensial dan berbagai potensi dasar atau fitrah manusia tersebut harus ditumbuhkembangkan secara optimal dan terpadu melalui proses pendidikan sepanjang hayatnya. Manusia diberi kebebasan atau kemerdekaan untuk berikhtiar mengembangkan alat-alat potensial dan potensi dasar atau fitrah manusia tersebut. Dengan demikian, dalam pertumbuhan dan perkembangannya tidak bisa dilepaskan dari adanya batas-batas tertentu, yaitu adanya hukum yang pasti dan tetap menguasai alam, benda-benda maupun masyarakat manusia sendiri, yang tidak tunduk dan tidak tergantung kepada kemauan manusia. Hukum inilah yang dinamakan dengan taqdir ("keharusan universal" atau "kepastian umum" sebagai batas akhir dariikhtiar manusia dalam kehidupannya di dunia). Dengan demikian, pendidikan Islam harus dapat menumbuhkembangkan seluruh potensi dasar (fitrah) manusia terutama potensi psikis dengan tidak mengabaikan potensi fisiknya. Dengan konsep fitrah, Islam mempunyai landasan tersendiri dalam bidang pendidikan. Konsep tersebut senantiasa menjadi ketentuan normatif dalam mengembangkan kualitas manusia melalui pendidikan. 
masyarakat tersebut. Maka dari itu pendidikan Islam harus didesain untuk menjawab perubahan tersebut. Usulan perubahan yang dimaksud meliputi: (a) pendidikan harus menuju pada integritas antara ilmu agama dan ilmu umum untuk tidak melahirkan jurang pemisah antara ilmu agama dan ilmu bukan agama, karena, dalam pandangan seorang muslim, ilmu pengetahuan adalah satu yaitu yang berasal dari Allah swt, (b) pendidikan menuju tercapainya sikap dan perilaku "toleransi", lapang dada dalam berbagai hal dan bidang, terutama toleran dalam perbedaan pendapat dan penafsiran ajaran Islam, tanpa melepaskan pendapat atau prinsipnya yang diyakini, (c) pendidikan yang mampu menumbuhkan kemampuan untuk berswadaya dan mandiri dalam kehidupan, (d) pendidikan yang menumbuhkan ethos kerja, mempunyai aspirasi pada kerja, disiplin dan jujur, (e) pendidikan Islam harus didesain untuk mampu menjawab tantangan masyarakat di era globalisasi.

Kedua, Reorientasi visi dan misi pendidikan Islam. Hal ini merupakan penjabaran atau spesifikasi dari misi pendidikan Islam itu sendiri, yaitu membentuk insan kamil. Selain itu, visi dan misi tersebut juga perlu disesuaikan dengan latar belakang, kondisi lokal masing-masing, dan didasarkan pada nilai-nilai ajaran Islam serta nilai-nilai budaya.

Dalam upaya menyusun visi pendidikan Islam, Teuku Amiruddin, mengusulkan perlu mempertimbangkan lima visi dasar pendidikan manusia abad 21, sebagaimana yang diajukan oleh UNESCO yaitu: 1) learning to know (belajar untuk mengetahui, berfikir, bersikap kritis dan rasional), 2) learning to do (belajar untuk berbuat, untuk bekerja profesional, dan untuk meningkatkan skill, 3) learning to be (belajar menjadi diri sendiri, belajar menyadari jati diri, untuk berkepribadian) dan 4) learning to live together (belajar hidup bersama orang lain, hidup dalam suasana pluralis, saling mengenal dan menghormati). (Wuri Soedjatmiko, 2000: 55-58; Mastuhu, 2004: 132-135).

Apabila konsep Islam dan UNESCO ini dipadukan, barangkali akan menjadi alternatif baru bagi pendidikan Islam. Artinya pendidikan Islam 
dapat dikembangkan dengan mengedepankan rasionalitas, sikap kritis, mandiri, mampu memecahkan masalah, mengembangkan sikap kreatif, memiliki daya fikir imajinatif, toleransi, menghargai hak asasi manusia serta siap bersaing dalam dunia global yang dilandasi dengan nilai-nilai Islam.

Ketiga, reorientasi strategi pendidikan Islam. Pembangunan pendidikan dan pendidikan Islam di Indonesia sekurang-kurangnya menggunakan empat strategi dasar, yaitu: a) pemerataan kesempatan untuk memperoleh pendidikan, b) relevansi pendidikan, c) peningkatan kualitas pendidikan, dan d) efesiensi pendidikan. Secara umum, strategi itu dapat dibagi menjadi dua dimensi, yakni peningkatan mutu dan pemerataan pendidikan. Pembangunan peningkatan mutu dapat meningkatkan efesiensi, efektifitas dan produktifitas pendidikan, sedangkan dimensi pemerataan pendidikan diharapkan dapat memberikan kesempatan yangsama dalam memperoleh pendidikan bagi semua usia sekolah. (Sanaky: 144).

Untuk menjamin kesempatan memperoleh pendidikan yang merata di semua kelompok strata dan wilayah tanah air sesuai dengan kebutuhan dan tingkat perkembangannya, maka perlu menyusun strategi dan kebijakan pendidikan Islam, yaitu: a) menyelenggarakan pendidikan Islam yang relevan dan bermutu sesuai dengan kebutuhan masyarakat Indonesia dalam menghadapi tantangan global; b) menyelenggarakan pendidikan Islam yang dapat dipertanggung jawabkan kepada masyarakat; c) menyelenggarakan pendidikan Islam yang demokratis secara profesional; d) meningkatkan efisiensi internal dan eksternal pada semua jalur, jenjang dan jenis pendidikan; e) memberi peluang yang luas dan meningkatkan kemampuan masyarakat, sehingga terjadi diversifikasi program pendidikan sesuai dengan sifat multikultural bangsa Indonesia; f) secara bertahap mengurangi peran pemerintah menuju ke peran fasilitator dalam implementasi sistem pendidikan Islam, dan g) merampingkan birokrasi pendidikan Islam sehingga lebih lentur (fleksibel) untuk melakukan 
penyesuaian terhadap dinamika perkembangan masyarakat dalam lingkungan global. (Sanaky: 145).

Keempat, reorientasi tujuan pendidikan Islam. Tujuan pendidikan Islam yang ada sekarang ini, dirasakan tidaklah benar-benar diarahkan pada tujuan yang positif, tetapi masih berorientasi pada tujuan hidup ukhrawi semata dan cenderung bersifat defensif, yaitu upaya menyelamatkan kaum muslim dari pencemaran dan pengrusakan yang ditimbulkan oleh dampak gagasan Barat yang datang melalui berbagai disiplin ilmu, terutama gagasan yang mengancam akan meledakkan standar-standar tradisional Islam. (Moeflich Hasbullah, 2000: 27 dan Abdurrahmansyah, 2005: 145. Implikasinya, rumusannya lebih bersifat normatif dan tidak bersifat problematik.

Untuk mengantisipasi hal tersebut, rumusan tujuan pendidikan Islam diharapkan lebih bersifat antisipatif, menyentuh aspek aplikasi dan dapat menyentuh kebutuhan masyarakat atau pengguna lulusan. Artinya, pendidikan Islam harus berupaya membangun manusia dan masyarakat yang utuh dan menyeluruh (insân kâmil) dalam semua aspek kehidupan yang berbudaya dan berperadaban yang tercermin dalam kehidupan manusia bertakwa dan beriman, berdemokrasi dan merdeka, berpengetahuan, berketerampilan, beretos kerja dan beramal saleh, berkepribadian dan berakhlakul karimah, berkemampuan inovasi dan mengakses perubahan serta berkemampuan kompetitif dan kooperatif dalam era global dan berpikir lokal dalam rangka memperoleh kebahagiaan duniawi dan ukhrawi. Dalam kerangka ini, dapat dikatakan bahwa tujuan pendidikan Islam yang dirumuskan meliputi aspek ilahiyyah (teosentris), fisik dan intelektual, kebebasan, akhlak, professional dalam rangka mewujudkan manusia yang berbudaya dan berperadaban, berkualitas, kreatif, dinamis sebagai insân kâmil dalam kehidupannya.

Kelima, reorientasi kurikulum pendidikan Islam. Dalam bidang kurikulum, kurikulum pengajaran masih didominasi oleh masalah-masalah yang bersifat normatif, ritualistikdan eskatologis. Apalagi materi ini 
kemudian disampaikan dengan semangat ortodoksi keagamaan yang memaksa peserta didik tunduk pada suatu meta narasi yang ada, tanpa diberi peluang untuk melakukan telaah secara kritis.

Bukan ortopraksis yaitu bagaimana mewujudkan iman dalam tindakan nyata operasional. (Amin Abdullah, 1998: 49-65). Amin Abdullah juga menyoroti kurikulum dan kegiatan pendidikan Islam yang selama ini berlangsung, yaitu:

1) Pendidikan Islam lebih terkonsentrasi pada persoalan-persoalan teori keagamaan yang bersifat kognitif semata serta amalan-amalan ibadah praktis;

2) Pendidikan Islam kurang concern terhadap bagaimana mengubah pengetahuan agama yang kognitif menjadi "makna' dan "nilai" yang perlu diinternalisasikan dalam diri siswa lewat berbagai cara, media, dan forum;

3) Pendidikanagama lebih menekankan pada aspek korespondensitekstual, yang lebih menekankan pada aspek hafalan teks-teks keagamaan yang ada;

4) Bentuk-bentuk soal ujian agama dalam sistem evaluasi menunjukkan prioritas utama pada aspek kognitif dan belum mempunyai bobot muatan "nilai dan "makna" spiritual keagamaan yang fungsional dalam kehidupan sehari-hari.

Pada akhirnya agama dipandang sebagai sesuatu yang final yang harus diterima secara taken for granted. (Malik Fajar, 1999: 115-132; Martin van Bruinessen, 1995: 29;). Mencermati beberapa kelemahan kurikulum pendidikan Islam di atas, maka dalam desain kurikulum harus diorientasikan pada: a) kemampuan mengetahui caraberagama yang benar; b) mempelajari Islam sebagai sebuah pengetahuan, sehingga diharapkan dapat terbentuk perilaku manusia muslim yang memiliki komitmen, loyal serta dedikasi terhadap ajaran Islam dan sekaligus sebagai ilmuwan, peneliti, pengamat yang kritis untuk pengembangan keilmuan Islam yang memiliki kemampuan inovasi serta siap menerima dan 
menghadapi tantangan perubahan. (Sanaky: 167). Strategi pengembangan pendidikan Islam harus didasarkan pada kurikulum yang secara integral memiliki cakupan disiplin ilmu dan keterampilan yang dapat membentuk kompetensi-kompetensi tertentu dalam suatu sistem yang utuh walaupun komponennya secara transparan berbentuk berbagai macam disiplin ilmu dan teknologi. (Jusuf Amir Feisal: 1995: 51).

Keenam, reorientasi metodologi pendidikan Islam. Harus diakui bahwa metodologi pendidikan Islam yang berjalan saat ini masih sebatas pada sosialisasi nilai dengan pendekatan hafalan dan hanya mewariskan sejumlah materi ajaran agama yang diyakini benar untuk disampaikan kepada anak didik tanpa memberikan kesempatan kepada anak didik agar disikapi secara kritis, mengoreksi, mengevaluasi dan mengomentari. Sasaransetiap proses pembelajaran ditekankan pada asimilasi pembelajaran (miximizing "student learning"), dan bila perlu mengurangi porsi ceramah guru (minimizing "teacher teaching") dengan mengaktifkan peserta didik untuk mencari dan menemukan serta melakukan aktivitas belajar sendiri, sehingga konsep metodologi yang terbangun adalah pembelajaran (learning) bukan pengajaran (teaching).

Maka dari itu, metode pendidikan Islam yang digunakan adalah pembelajaran dengan menggunakan paradigma holistik, rasional, partsipatori, pendekatan empirik-deduktif, sehingga menghasilkan peserta didik yang berkualitas, kreatif, inovatif yang mampu menerjemahkan dan menghadirkan agama dalam perilaku sosial dan individual di tengah-tengah kehidupan masyarakat modern. Mampu mengembangkan dan mengamalkan ilmu serta keahliannya dengan bersumber pada ajaran Islam. Menjadikan ajaran Islam sebagai pedoman keseharian, baik sebagai individu atau sebagai ilmuwan di tengah kehidupan modern yang semakin mengglobal, kompleks, kompetitif dalam kehidupan masyarakat rabbani Indonesia. Selain itu, metode pendidikan Islam harus dapat mengembangkan potensi manusia demokratis yang bebas dari ketakutan, 
bebas berekspresi, dan bebas untuk menentukan arah kehidupannya sesuai dengan ciri masyarakat rabbani Indonesia.

Ketujuh, reorientasi manajemen dan sumber daya pendidikan Islam. Masalah klasik yang menjadi problem pokok pendidikan Islam adalah ketidakjelasan arah pengelolaan dan rendahnya kualitas sumberdaya manusia pengelola pendidikan. Hal ini terkait dengan program kependidikan yangmasihlemah dan pola rekrutmen tenaga kependidikan yang kurang selektif.

Dengan demikian, masih lemahnya manajemen pendidikan sampai dewasa ini perlu disikapi dengan ketekunan untuk mengoptimalkan pengelolaan lembaga pendidikan. Otonomi bidang pendidikan yang menetapkan pembagian kewenangan pengelolaan bidang pendidikan dan kebudayaan antara pemerintah pusat, provinsidan kabupaten/kotaadalah menuntut pengelolaan pendidikan secara lebih baik. Untuk itu diperlukan para manajer institusi pendidikan yang profesional, kredibel dan akuntabel dalam menjalankan program pendidikan nasional, tak terkecuali semua pimpinan lembaga pendidikan Islam. (Syafaruddin, 2005: 5).

Berbagai sumber daya (resources) yang dimiliki lembaga pendidikan Islam harus dikerahkan dan dimanfaatkan untuk dapat menghadapi perubahan eksternal yang dipengaruhi dinamika politik, ekonomi, sosial dan budaya. Pimpinan lembaga pendidikan Islam harus mendesain format pendidikan yang kompetitif dan inovatif untuk keperluan masa depan. Hanya dengan kesiapan manajemen pendidikan yang efektif, lembaga pendidikan Islam dapat merespon perubahan sehingga tidak akan mengalami stagnasi (kemacetan) dan ketinggalan dalam dinamika perubahan yang cepat. (Syafaruddin, 2005: 1-2).

Berdasarkan reorientasi tersebut di atas, maka lembaga-lembaga pendidikan Islam seyogyanya mulai memikirkan kembali desain program pendidikan untuk menuju masyarakat rabbani, dengan memperhatikan relevansinya dengan bentuk atau kondisi serta ciri masyarakat rabbani. Maka untuk menuju masyarakat rabbani, lembaga-lembaga pendidikan 
Islam harus memilih satu diantara dua fungsi yaitu apakah mendesain model pendidikan umum Islami yang handal dan mampu bersaing secara kompotetif dengan lembaga pendidikan umum atau mengkhususkan pada desain pendidikan keagamaan yang handal dan mampu bersaing secara kompotetif, misalnya mempersiapkan ulama-ulama dan mujtahid-mujtahid yang berkaliber nasional dan dunia.

\section{PEMBAHASAN}

Konsep masyarakat rabbani dalam menumbuhkan fitrah kebaikan merupakan tuntutan baru yang memerlukan berbagai torobosan di dalam berpikir, penyusunan konsep, serta tindakan-tindakan. Dengan kata lain, dalam menghadapi perubahan masyarakat dan zaman konstalasi global yang serba digital native, diperlukan suatu paradigma baru di dalam menghadapi tuntutan-tuntutan yang baru, karena apabila tantangantantangan baru tersebut dihadapi dengan menggunakan paradigma lama, maka segala usaha yang dijalankan akan menemui kegagalan.

Terobosan pemikiran kembali konsep dasar pembaharuan pendidikan Islam menuju masyarakat rabbani sangat diperlukan dalam rangka menumbuhkan fitrah kebaikan dalam mengemban amanah besar sebagai rahmatan lil alamiin, karena pendidikan merupakan sarana terbaik yang didesain untuk menciptakan suatu generasi baru yang tidak akan kehilangan ikatan dengan tradisi mereka sendiri tapi juga sekaligus tidak menjadi bodoh secara intelektual atau terbelakang dalam pendidikan mereka atau tidak menyadari adanya perkembangan-perkembangan di setiap cabang pengetahuan manusia. Maka perlu adanya reorientasi pada bidang dasar pendidikan Islam,yaitu:

1. ReorientasiKerangka Dasar Filosofis Dan Teoritis Pendidikan

Konsep dasar pendidikan dalam pelaksanaannya sudah tidak sesuai dengan pemaknaan pendidikan Islam. Maka tantangan utama yang dihadapi sia-sia dan diamanatkan-Nya kepada manusia sebagai khalifah dimuka bumi ini untuk diolah umat Islam sekarang adalah peningkatan mutu sumber insaninya dalam menempatkan diri dan memainkan perannya 
dalam komunitas masyarakat rabbani dengan menguasai ilmu dan teknologi yang berkembang semakin pesat. Karena, hanya mereka yang menguasai ilmu dan teknologi modern dapat mengolah kekayaan alam yang telah diciptakan Allah untuk manusia bagi kesejahteraan umat manusia.

Konsep filsafat dan teoritis pendidikan Islam dikembangkan sebagai prinsip-prinsip yang mendasari keterlaksanaannya dalam kontek lingkungan masyarakat rabbani tersebut, sehingga pendidikan relevan dengan kondisi dan ciri sosial kultural masyarakat tersebut. Pendidikan Islam harus didesain untuk menjawab perubahan tersebut. Usulan perubahan yang dimaksud meliputi: (a) pendidikan harus menuju pada integritas antara ilmu agama dan ilmu umum untuk tidak melahirkan jurang pemisah antara ilmu agama dan ilmu bukan agama, karena, dalam pandangan seorang muslim, ilmu pengetahuan adalah satu yaitu yang berasal dari Allah swt, (b) pendidikan menuju tercapainya sikap dan perilaku "toleransi", lapang dada dalam berbagai hal dan bidang, terutama toleran dalam perbedaan pendapat dan penafsiran ajaran Islam, tanpa melepaskan pendapat atau prinsipnya yang diyakini, (c) pendidikan yang mampu menumbuhkan kemampuan untuk berswadaya dan mandiri dalam kehidupan, (d) pendidikan yang menumbuhkan ethos kerja, mempunyai aspirasi pada kerja, disiplin dan jujur, (e) pendidikan Islam harus didesain untuk mampu menjawab tantangan masyarakat di era globalisasi.

Secara teori yang dikuatkan hasil penelitian tersebut di atas, kerangka dasar filosofis dan teoritis pendidikan telah memenuhi kreteria pendidikan Islam, pada tataran pelaksanaan yang belum sesuai sehingga penumbuhan fitrah kebaikan sesuai tujuan pendidikan yang rabbani belum mampu terwujud. Permasalahannya adapada konsep dasar pendidikan Islam yang sudah baik, tetapi pada pelaksanaan jauh melenceng dari nilai filosofis pendidikan Islam. Bukan lagi mengacu pada konsep tarbiyah yang mengutamakan tauhid atau akidah, bukan lagi peserta didik yang mensifati ketaatan, mengikut, dan keteladanan, tetapi digantikan dari murid menjadi 
peserta didik, sehingga nama peserta yang semaunya sendiri. Ini menjadi salah satu faktor yang sangat fatal akibatnya jika tidak kita luruskan. Tentu akan menghasilkan generasi biadab, karena jauh dari akidah dan akhlak. Sehingga lahir generasi yang jauh dari agama, karena tidak sinerginya antara pendidikan di keluarga, di sekolah, dan di masyarakat, terutama masjid tidak dipandang sebagai salah satu pusat pendidikan. Jika ingin mencapai pertumbuhan fitrah kebaikan maka pendidikan harus tidak boleh tidak kembali pada konsep dasar tarbiyah yang mendasari pada penanaman akidah dan akhlak.

\section{Reorientasi Visi Dan Misi Pendidikan Islam}

Reorientasi visi dan misi pendidikan Islam. Hal ini merupakan penjabaran atauspesifikasi dari misi pendidikan Islam itu sendiri, yaitu membentuk insan kamil yang berfungsi mewujudkan rahmatan li al-ālaminn. Selain itu, visi dan misi tersebut juga perlu disesuaikan dengan latar belakang, kondisi lokal masing-masing, dan didasarkan pada nilai-nilai ajaran Islam serta nilai-nilai budaya).

Reorientasi reorientasi visi dan misi pendidikan Islam dapat mengacu pada konsep pendidikan yang ditawarkan UNESCO yaitu: 1) learning to know (belajar untuk mengetahui, berfikir, bersikap kritis dan rasional), 2) learning to do(belajar untuk berbuat, untuk bekerja profesional, dan untuk meningkatkan skill, 3) learning to be (belajar menjadi diri sendiri, belajar menyadari jati diri, untuk berkepribadian) dan 4) learning to live together (belajar hidup bersama orang lain, hidup dalam suasana pluralis, saling mengenal dan menghormati. Dalam mewujudkan konsep rahmatan li al- 'ālamīn kita dapat melihat dengan cermat bahwa apa yang telah dicanangkan oleh pemerintah melalui sekolah sudah optimal bahkan jika berjalan sesuai dengan pendidikan yang ada, maka akan melahirkan generasi yang rabbani, tetapi semua tidak berjalan sinergi antara kurikulum, pimpinan sekolah-sekolah, dan guru, terutama guru yang masih belum mampu menjadi fasilitator pembelajaran dengan baik, sehingga berdampak pada hasil, peserta didik terlihat tidak mendapatkan apa-apa dari proses 
belajar mengajar karena tidak ada yang dicontoh dan parahnya tidak ada yang diperoleh dari diri seorang guru. Jika hal initerus berlanjut maka tidak menutup kemungkinan fitrah kebaikan yang ada pada diri peserta didik akan mati karena lingkungan yang tidak mampu menghidupkan. Fitrah kebaikan akan tumbuh dengan baik jika pendidikan mengusung visi dan misi sebagai rahmatan li al-‘âlaminn.

\section{Reorientasi Strategi Pendidikan Islam}

Reorientasi strategi pendidikan Islam setidaknya mengacu pada empat strategi dasar, yaitu: a) pemerataan kesempatan untuk memperoleh pendidikan, b) relevansi pendidikan, c) peningkatan kualitas pendidikan, dan d) efesiensi pendidikan. Secara umum, strategi itu dapat dibagi menjadi dua dimensi, yakni peningkatan mutu dan pemerataan pendidikan. Pembangunan peningkatan mutu dapat meningkatkan efisiensi, efektifitas dan produktifitas pendidikan, sedangkan dimensi pemerataan pendidikan diharapkan dapat memberikan kesempatan yang sama dalam memperoleh pendidikan bagi semua usia sekolah.

Berdasarkan konsep visi misi besar tujuan pendidikan Islam membentuk generasi Islam yang mengemban tanggung jawab rahmatan li al-'ālamīn maka dibutuhkan strategi pendidikan Islam. Namun yang ada dilapangan hampir proses pembelajaran pada pendidikan Islam masih belum mengoptimalkan konsep dasar strategi dalam mencapai tujuan tetapi lebih berjalan apa adanya.

Strategi pendidikan Islam merupakan suatu konsep yang harus mendasari pada setiap lembaga pendidikan Islam dan harus menjadi semangat baru dalam mewujudkan kesamaan mutu pendidikan dan pemerataan pendidikan antara perkotaan dan pedesaan. Sehingga misirahmatan li al-ālamīn dapat tercapai dengan baik. Dengan strategi pendidikan Islam yang matang dan merata maka akan semakin mudah mewujudkan fitrah kebaikan pada generasi yang rabbani.

4. Reorientasi Tujuan Pendidikan Islam dalam menumbuhkan fitrah kebaikan 
Tujuan pendidikan Islam yang tidak sesuai dengan arah dan tujuan sabagaimana yang digambarkan beberapa kesalahpahaman umum tentang pendidikan dan sekaligus pandangan alternatifnya sebagai berikut:

\begin{tabular}{|c|c|c|}
\hline Komponen & Seharusnya & Senyatanya \\
\hline Visi & $\begin{array}{l}\text { Pendidikan dipandang secara } \\
\text { holistik, menyeluruh dan } \\
\text { berparadigma rekonstruktif. }\end{array}$ & $\begin{array}{l}\text { Pendidikan dianggap sebagai } \\
\text { disiplin yang terpisah; } \\
\text { partikularistik, masih memakai } \\
\text { paradigma mekanistik (model } \\
\text { perusahaan). }\end{array}$ \\
\hline Tujuan & $\begin{array}{l}\text { Beyond schooling, } \\
\text { bagaimana belajar (how to } \\
\text { learn), pembelajaran seumur } \\
\text { hidup (life long education), } \\
\text { pengembangan manusia } \\
\text { seutuhnya (khaira ummah). }\end{array}$ & $\begin{array}{l}\text { Perolehan informasi ansich, } \\
\text { pengetahuan dan keterampilan } \\
\text { hanya untuk perolehan } \\
\text { pekerjaan (promise of job). }\end{array}$ \\
\hline Isi & $\begin{array}{l}\text { Pembelajaran bersifat } \\
\text { kontekstual, transformatif, } \\
\text { realistik, kurikulum berbasis } \\
\text { kehidupan nyata. }\end{array}$ & $\begin{array}{ll}\text { Pembelajaran } & \text { bersifat } \\
\text { konvensional, } & \text { sekadar } \\
\text { informatif, tidak relevan } \\
\text { dengan kehidupan riil peserta } \\
\text { didik, hanya terfokus pada } \\
\text { instruksi/pengajaran textbook. }\end{array}$ \\
\hline Struktur & $\begin{array}{l}\text { Gagasan } \text { bersifat } \\
\text { (powerful ideas), mampu } \\
\text { memberi inspirasi dan } \\
\text { transformasi, } \quad \text { mampu } \\
\text { membangun kepribadian dan } \\
\text { jati diri anak. }\end{array}$ & $\begin{array}{l}\text { Struktur tidak koheren atau } \\
\text { disusun oleh disiplin akademik } \\
\text { yang rigid. }\end{array}$ \\
\hline Metode & $\begin{array}{l}\text { Discovery learning, terpusat } \\
\text { pada murid, pengajaran }\end{array}$ & $\begin{array}{l}\text { Didaktik (ceramah, monolog); } \\
\text { guru sebagai pusat, satu model }\end{array}$ \\
\hline
\end{tabular}




\begin{tabular}{|c|c|c|}
\hline Komponen & Seharusnya & Senyatanya \\
\hline & 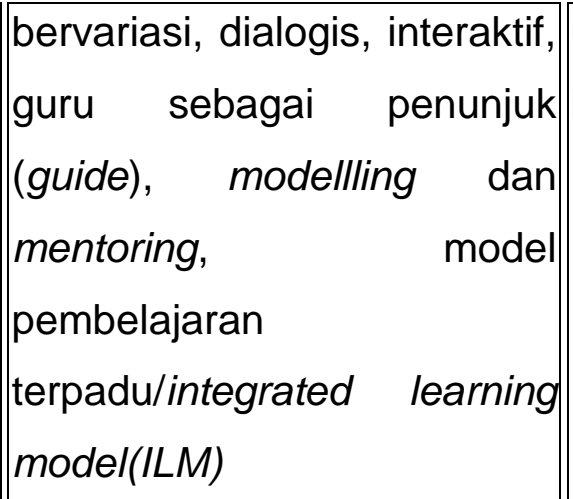 & $\begin{array}{l}\text { untuk semua murid, tidak } \\
\text { inspiratif. }\end{array}$ \\
\hline Program & 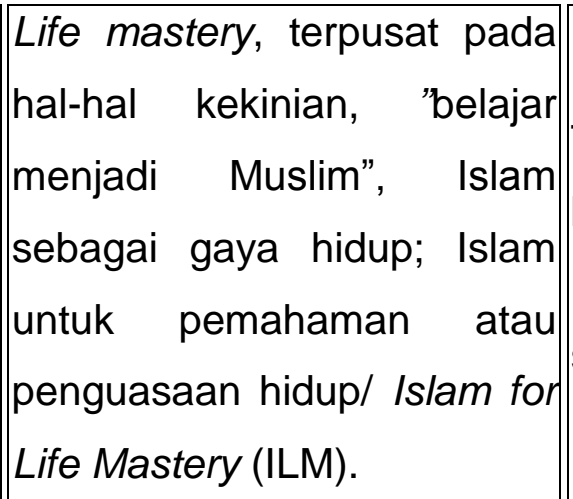 & $\begin{array}{l}\text { Terfokus pada masa lampau, } \\
\text { belajar tentang Islam dan } \\
\text { kepemilikan Islam, ritual- } \\
\text { seremonial. }\end{array}$ \\
\hline Penilaian & \begin{tabular}{|l} 
Authentic \\
berhubungan dengan dunia \\
riil, penilaian \\
intelligensi.
\end{tabular} & $\begin{array}{l}\text { Tes formal bersifat textbook, } \\
\text { benar- salah, lulus atau tidak } \\
\text { lulus, tes standar. }\end{array}$ \\
\hline
\end{tabular}

Saat ini tuntutan pendidikan bukan lagi menjawab tentang esensi keilmuan tetapi sudah mengarah pada kebutuhan pasar. Tiga kutup pendidikan orang tua, sekolah, dan masyarakat terjebak pada sikap duniawi yang sesaat.Pendidikan Islam belum sesuai dengan strategi pendidikan Islam yang mengacu pada persamaan mutu pendidikan dan pemerataan pendidikan dalam rangka mewujudkan generasi yang mampu menjadi rahmatan li al-'ālamīn. Jika menginginkan peserta didik menjadi rahmatan li al-ālamīn maka pendidikan Islam pada prosesnya dibutuhkan strategi besar yaitu peningkatan mutu dan pemerataan pendidikaan sehingga 
mudah menumbuhkan fitrah kebaikan yang menjadi dasar generasi rabbani manjadi rahmatan li al-‘ālamīn.

5. Reorientasi Kurikulum Pendidikan Islam

Kurikulum pengajaran masih didominasi oleh masalah-masalah yang bersifat normatif, ritualistik dan eskatologis. Apalagi materi ini kemudian disampaikan dengan semangat ortodoksi keagamaan yang memaksa peserta didik tunduk pada suatu meta narasi yang ada, tanpa diberi peluang untuk melakukan telaah secara kritis.

Kurikulum dan kegiatan pendidikan Islam yang selama ini berlangsung, yaitu: 1)pendidikan Islam lebih terkonsentrasi pada persoalan-persoalanteori keagamaan yang bersifatkognitif semata serta amalan-amalan ibadah praktis; 2) pendidikan Islam kurang concern terhadap bagaimana mengubah pengetahuan agama yang kognitif menjadi "makna" dan "nilai" yang perlu diinternalisasikan dalam diri siswa lewat berbagai cara, media, dan forum; 3) pendidikan agama lebih menekankan pada aspek korespondensi-tekstual, yang lebih menekankan pada aspek hafalan teks-teks keagamaan yang ada; 4) bentuk-bentuk soal ujian agama dalam sistem evaluasi menunjukkan prioritas utama pada aspek kognitif dan belum mempunyai bobot muatan nilai danmakna spiritual keagamaan yang fungsional dalam kehidupan sehari-hari”.

Pendidikan Islam pada tataran konsep kurikulum sudah bagus, tetapi pada tataran pelaksanaan masih belum sesuai harapan. Kurikulum pendidikan Islam akan baik jika kurikulum dijalankan dengan proses yang baik dan akan menghasilkan keluaran yang baik juga hasilnya akan melahirkan ulama kecil. Sudah pasti bila guru mampu menjadi fasilitator yang mampu menjadi sentral dan teladan maka proses menumbuhkan fitrah kebaikan dan tentu akan menjadi kenyataan visi misi besar pendidikan Islam yaitu menjadi generasi yang mampu mengemban amanah.

Kurikulum pendidikan Islam sudah sangat baik pada tataran konsep, pada tataran proses yang masih belum optimal, dimana secara struktural dari MI, MTs, dan MA, bahkan sampai PT jika memperhatikan 
proses yang baik untuk mendapatkan hasil yang baik akan melahirkan ilmuwan agama.

6. Reorientasi Metodologi Pendidikan Islam

Metodologi pendidikan Islam yang berjalan saat ini masih sebatas pada sosialisasi nilai dengan pendekatanhafalan dan hanya mewariskan sejumlah materi ajaran agama yang diyakini benar untuk disampaikan kepada anak idik tanpa memberikan kesempatan kepada peserta didikagar disikapi secara kritis, mengoreksi, mengevaluasi dan mengomentari.

Terpenuhinya misi pendidikan tersebut sangat tergantung pada kemampuan guru untuk menanamkan seting demokrasi pada peserta didiknya dengan memberi kesempatan seluas-luasnya pada peserta didik untuk belajar, yakni bahwa sekolah menjadi tempat yang nyaman bagi peserta didik untuk semaksimal mungkin mereka belajar. Sekolah bukan tempat pertunjukan bagi guru, tetapi tempat peserta didik untuk menambah dan memperkaya pengalaman belajarnya. Oleh sebab itu, pendidik harus mampu mengembangkan strategi pembelajaran yang memberi peluang lebih besar bagi mereka untuk belajar. Sekolah harus menjadi second home bagi para peserta didik, mereka betah menghabiskan waktunya di sekolah, dengan belajar, berdiskusi, menyelesaikan tugas-tugas kelompok, membaca dan aktivitas pembelajaran lainnya.

Apabila konsep tersebut dilaksanakan, tentu akan menuntut fungsi pendidik sebagai fasilitator, dinamisator, mediator dan motivator, sehingga dapat memberdayakan peserta didik untuk mampu mencari dan menemukan sendiri informasi yang diterimanya. Pendidik berupaya menciptakan iklim belajar yang kondusif, sehingga peserta didik dapat belajar dalam suasana yang dialogis, harmonis dan demokratis.

7. Reorientasi Manajemen Dan Sumber Daya Pendidikan Islam Dalam MenumbuhkanFitrah Kebaikan Pada Konstalasi Global

Guru dalam menjalankan profesinya berbegang teguh pada tiga tugas utama, yaitu tugas, yaitu tugas profesi, tugas kemanusiaan, dan tugas kemasyarakatan. pada era globalisasi mempengaruhi orientasi visi, misi, 
peran, dan fungsi guru. Penggunaan sains dan tekhnologi menyebabkan semakin mengecilnya peran dan fungsi guru, karena banyaknya tugastugas keguruan seperti penyampaian informasi dan pendidikan keterampilan yang sudah tergantikan tekhnologi. Pada dimensi "sakralitas" dan "kekudusan" seorang pendidik makin tergeser. wibawa, do'a, dan nasihatnya kurang lagi dimintakan, karena peran pendidik beralih menjadi fungsi-fungsi kebendaan, seperti fungsi fasilitator, katalisator, dan mediator.

Peran fungsi guru dalam mewujudkan visi dan misi guru PAI di era digital native atau era globalisasi mengalami kesulitan yang terstruktur dan tidak mampu memposisikan diri sebagai sosok sentral dan teladan dan disisi lain dituntut untuk menjalankan fungsi fasilitator, katalisator, dan mediator.

Posisi guru tersebut di atas menggaris bawahi bahwa secara khusus seorang guru agama harus memiliki sifat-sifat sebagai berikut: (1) senantiasa menyayangi peserta didiknya; (2) mau memberi nasihat; (3) bertujuan ibadah dalam mengajar; (4) lemah lembut; (5) tidak merendahkan pelajaran lain; (6) menyesuaikan dengan kemampuan peserta didiknya; (7) mengamalkan ilmu yang diajarkannya; (8) mendorong para peserta didik agar berpikir; (9) mengajarkan ilmu dimulai dari yang rendah; (10) bersikap adil terhadap semua peserta didik.

Sejalan dengan permasalahan yang ada, maka perlu kembali kepada visi dan misi, seorang guru yaitu visi sebagai ulul al bab, al-ulama, al-muzakki, ahl al-dzikr, dan al-rasikhuna fi al-ilm yang disesuaikan dengan tantangan dan kebutuhan zaman. Visi dan misi ini diantaranya adalah sebagai berikut.

1. Visi dan misi ulil al bab.

Berdasarkan petunjuk Al-Qur'an surah Al-Imran: 190-191 dapat diketahui, bahwa visi guru sebagai ulil al-bab adalah menjadi orang yang memiliki keseimbangan antara daya pikir dan daya nalar dengan daya zikir dan spiritual. Dengan daya ini, maka seorang guru mengemban misi 
mempergunakan dayanya itu secara optimal untuk melakukan amar ma'ruf nahi munkar, sehingga keberadaannya tidak menjadi orang yang sia-sia.

2. Visi dan misi al-ulama.

Berdasarkan petunjuk Al-Qur'an surah Fatir, (35) ayat 27-28 diketahui bahwa sebagai ulama ia menjadi orang yang mendalami ilmu pengetahuan melalui kegiatan penelitian terhadap alam jagad raya fauna, flora, ruang angkasa, geologi, fisika, dan sebagainya yang disertai keikutsertaan naluri intuisi dan fitrah batinnya untuk menyadari bahwa jagad raya yang dijadikan objek penelitiannya adalah ciptaan dari Allah swt.

3. Visi dan misi al-muzakki.

Bedasarkan petunjuk Al-Qur'an surah Al-Baqarah:129, dan AlImran: 164, dijelaskan bahwa visi guru adalah al-muzakki yaitu menjadi orang yang memiliki mental dan karakter yang mulia. Sedangkan misinya adalah membersihkan dirinya dan anak didiknya dari pengaruh akhlak yang buruk serta menjauhkan diri dari perbuatan dosa dan maksiat yang dilarang oleh Allah dan Rasulnya.

4. Visi dan misi ahl al-dzikr.

Bedasarkan petunjuk Al-Qur'an surah Al-Anbiya: 7, visi guru sebagai ahl al-dzikr adalah menjadi orang yang menguasai ilmu pengetahuan dan memiliki expert judgement, keahlian yang diakui kepakarannya sehingga ia pantas menjadi tempat bertanya, menjadi rujukan, dan memiliki otoritas untuk memberikan pembenaran atau pengakuan atas berbagai temuan ilmiah. Sedangkan misinya adalah memperbaiki, membimbing, meluruskan, dan mengigatkan serta memberikan keputusan atas perilaku yang dilakukan anak didiknya.

5. Visi dan misi al-rasikhuna fi al-'ilm.

Bedasarkan petunjuk Al-Qur'an surah An-Nisa': 162, diketahui bahwa visi al-rasikhuna fi al-'ilm adalah menjadi orang yang memiliki kemampuan bukan hanya pada dataran fakta dan data, inferensial, atau prestechen terhadap data dan fakta tersebut. Sedangkan misinya adalah memberi makna, semangat dan dorongan kepada anak didik dan 
masyarakat sekitarnya agar meningkatkan kualitas hidup dengan cara menghayati, memahami, dan mendalami makna yang terkandung didalamnya.

Kematangan dan kemampuan guru agama, ditinjau dari sisi kreteria tersebut masih belum memenuhi standard tetapi pada tataran al-rasikhuna fi al-ilm guru hampir seluruhnya telah melakukan peran dan fungsinya meskipunbelum maksimal.

Guru pada tataran visi ulul al bab, al-ulama, al-muzakki, ahl al-dzikr, dan al-rasikhuna fi al-ilm masih sangat jauh dan masih dibutuhkan suatu kerja keras perbaikan fisik, sarana dan prasarana, dan terutama proses pembelajaran yang dilakukan seorang guru. Guru harus dipersiapkan pada proes pembelajaran pada tataran sebagai seorang yang sakral yang memiliki wibawa yang harus di jaga dengan cara tugas utama yang harus dilakukan betul-betul telah terinternalisasi pada diri guru agama.

Implikasi visi dan misi guru di era globalisasi guru pada era digital native memiliki perjuangan yang sangat berat karena jihadnya perang melawan era digital yang aksesnya sulit terkontrol dan laju perkembangannya tidak dapat dielakan dengan kshidupan sehari-hari, sehingga guru pengembang misi suci, yakni menyelamatkan manusia dari kehancuran dan membawanya menuju kepada kemajuan dan keadaban.

Fenomena tersebut guru agama membutuhkan suatu kesiapan kompetensi dan professionalitas pada bidangnya. Profil guru yang profesional di era globalisasi, yaitu; 1) memiliki kepribadian yang matang dan berkembang, 2) penguasaan ilmu yang kuat, 3) keterampilan untuk mem-bangkitkan peserta didik kepada sains dan teknologi, dan 4) pengembangan profesi secara berkesinambungan. Keempat aspek tersebut merupakan satu kesatuan utuh yang tidak dapat dipisahkan dan ditambah dengan usaha lain yang ikut mempengaruhi perkembangan profesi guru yang professional.

Dampak dari era globalisisi terhadap visi dan misi guru agama dalam menjalankan tugasnya masih belum sesuai dengan tugas mulia 
mengemban tuas suci sebagai juru agama dan tugas utama dari profesinya yaitu profesi kemanusiaan, dan kemasyarakatan. Semua dapat dilihat dari proses pembelajaran yang tidak menekankan pada proses untuk mendapat hasil tetapi mengejar target hasil mengabaikan proses. Sehingga tindakan dan kepribadian guru hilang arah dan tidak mampuanmenjadi sentral dan teladan. Kerusakan pembelajaran, hilangnya ketaatan, hilangnya mengajak, dan mengikuti/dicontoh.

Dampak era globalisasi memberikan sangat besar terhadap peningkatan kualifikasi mutu guru agama dari berbagai sisi, baik sisi akidah, akhlak, keilmuan dan terutuma dalam menjalankan proses pembelajaran dan tugas utama sebagai pengemban visi misi guru agama di era globalisisi.

Berdasarkan reorientasi pendidikan Islam tersebut di atas, seharus lembaga pendidikan Islam mulai membuat perencanaan yang matang untuk menumbuhkan fitrah kebaikan. Reorientasi pendidikan Islam menjadi suatu yang sangat urgen dalam upaya menumbuhkan fitrah kebaikan pada murid pada era konstalasi global. Dimana era yang serba digital native jika tidak hati-hati akan tercipta generasi yang jauh dari agama dan akan semakin sulit terwujud generasi rabbani yang mampu mengemban amanah besar sebagai rahmatan li al-'âlamīn. Maka untuk menuju masyarakat rabbani, lembaga-lembaga pendidikan Islam harus mendesain pendidikan tanpa mendikotomikan keilmuan dengan desain pendidikan yang handal sehingga mampu untuk berkompetisi.

\section{KESIMPULAN}

Lembaga pendidikan Islam harus melakukan reorientasi kerangka dasar filosofis dan teoritis pendidikan. Peserta didik dari proses pembelajaran telah mengalami degradasi akhlak pada generasi muslim. Jika menginginkan proses menumbuhan fitrah kebaikan pada peserta didik di era konstalasi global maka perlu adanya reorientasi kerangka dasar filosofis pendidikan Islam, Selain itu perlu adanya reorientasi visi dan misi pendidikan Islam, Jika menginginkan peserta menjadi kembali ke 
fitrahnya,maka pendidikan Islam pada prosesnya dibutuhkan kemauan yang besar untuk mewujudkan visi dan misinya sehingga fitrah kebaikan yang telah ada pada diri peserta didik dapat tumbuh dengan baik sebagai insan kamil. Begitu pula diperlukan adanya Reorientasi Strategi Pendidikan Islam yaitu membutuhkan strategi besar untuk peningkatan mutu dan pemerataan pendidikan pada semua lembaga pendidikan.

Untuk menumbuhkan fitrah pada generasi sekarang maka guru perlu penumbuhan karakter visi ulul al-bab, al-ulama, al-muzakki, ahl aldzikr, dan al-rasikhuna fi al-ilm dan memposisikan pendidik yang berwibawa dan memiliki sakralitas. Selain itu juga perlu optimalisasi pembelajaran dan internalisasi tugas utama guru sebagai profesi, kemanusiaan, dan kemasyarakatan, sehingga akan terbangun pendidik pendidikan Islam yang sesuai dengan visi dan misinya. Perlunya peningkatan kualifikasi atau mutu pendidik pendidikan Islam dari berbagai sisi, baik sisi akidah, akhlak, keilmuan dan terutuma dalam menjalankan proses pembelajaran dan tugas utama sebagai pengemban visi misi pendidik di era globalisasi.

\section{DAFTAR PUSTAKA}

[1] Abdullah, Amin. "Problem Epistemologis-Metodologis Pendidikan Islam" dalam Abd. Munir Mulkan, et.al, Religiusitas IPTEK Yogyakarta: Pustaka Pelajar, 1998.

[2] Abdurrahmansyah, Wacana Pendidikan Islam, Khazanah Filosofis dan Implementasi Kurikulum, Metodologi dan Tantangan Pendidikan Moralitas Yogyakarta: Global Pustaka Utama, 2005.

[3] Azra, Azyumardi. Pendidikan Islam, Tradisi dan Modernisasi di Tengah Tantangan Millenium III Cet. III; Jakarta: Predanamedia Group, 2014.

[4] Fajar, Malik. Reorientasi Pendidikan Islam Jakarta: Fajar Dunia, 1999.

[5] Feisal, Jusuf Amir. Reformasi Pendidikan Islam Jakarta: Gema Insani Press, 1995. 
[6] Ghafur, A. Hanief Saha. Manajemen Mutu, Penjaminan Mutu Dan Internasionalisasi Perguruan Tinggi Di Indonesia Jakarta: UI Press, 2009.

[7] Hasbullah, Moeflich. "Pengantar Editor, Proyek Islamisasi Sains: Dekonstruksi Modernitas dan Rekonstruksi Alternatif Islam," dalam Gagasan dan Perdebatan Islamisasi IImu Pengetahuan Jakarta: Pustaka Cidesindo, 2000.

[8] Istadi, Irawati. Rumahku Tempat Belajarku Yogyakarta: Pro-U Media, 2017.

[9] Jumaeda dan Nur Khozin, Implementasi Kurikulum 2013 dalam Pembelajaran PAl, Ambon: Cet. I, LP2M IAIN Ambon, 2018

[10] Khozin Nur, Abdullah Pelupessy, Saddam Husein, Jurnal AlIltizam Vol. 3, No. 1, 2018 http://jurnal.iainambon.ac.id/index.php/ ALT/issue/view/66

[11] Mastuhu, Menata Ulang Pemikiran Sistem Pendidikan Nasional dalam Abad 21 Yogyakarta: Safiria Insania Press, 2004.

[12] Muhaimin, Paradigma Pendidikan Islam, Upaya Mengefektifkan Pendidikan Agama Islam di Sekolah Bandung: Remaja Rosdakarya, 2002.

[13] Saddam, Samad Umarella M. Sahrawi Saimima. "MEDICAL URGENCE IN THE LEARNING PROCESS." al-Iltizam: Jurnal Pendidikan Agama Islam 3.2 (2018): 237-245.

[14] Soedjatmiko, Wuri. "Pendidikan Tinggi dan Demokrasi" dalam Menggagas Paradigma Baru Pendidikan; Demokratisasi, Otonomi, Civil Society, Globalisasi, Ed. Sindhunata Yogyakarta: Kanisius, 2000.

[15] Solichin, Mohammad Muchlis. "Fitrah; Konsep dan Pengembangannya dalam Pendidikan Islam" dalam Tadrîs Jurnal Pendidikan Islam Volume 2. Nomor 2. 2007.

[16] Syafaruddin, Manajemen Lembaga Pendidikan Islam Jakarta: Ciputat Press, 2005. 
[17] Undang-Undang Nomor 12 Tahun 2012 pasal 5. Tentang Pendidikan Tinggi. 